\title{
REKONSEPSI PENDIDIKAN TAHFIZ AL QUR'AN MELALUI MODEL LEARNING STYLES PADA ANAK USIA SEKOLAH DASAR
}

\author{
Ahmad Shofiyuddin Ichsan \\ Institut Ilmu Al Qur'an An Nur Yogyakarta \\ ahmad.shofiyuddin.ichsan@gmail.com
}

\begin{abstract}
The research aims to reveal how to conceptualize the education of the Qur'an's tahfiz in student's primary school, especially in Madrasah Ibtidaiyah, through their learning styles. This research is a qualitative research with a descriptive analysis approach. The results showed that model of learning styles in the process of memorizing the Qur'an can be analyzed through the Memletics Learning Styles Inventory model, namely the learning style (read: memorizing) which is divided into seven parts, including: 1). Visual Memorization Style, 2). Aural Memorization Style, 3). Verbal Memorization Style, 4). Kinesthetic Memorization Style, 5). Logical Memorization Style, 6). Social Memorization Style, and 7). Solitori Memorization Style.
\end{abstract}

Keywords: Tahfiz Education, Learning Styles, Primary School

\begin{abstract}
ABSTRAK
Penelitian bertujuan untuk mengungkapkan bagaimana merekonsepsi pendidikan tahfiz Al Qur'an peserta didik di usia sekolah dasar, khususnya di Madrasah Ibtidaiyah, melalui model learning styles (gaya belajar) mereka masingmasing. Penelitian ini merupakan penelitian kualitatif dengan pendekatan deskriptif analisis. Hasil penelitian menunjukkan bahwa model learning styles (gaya belajar) dalam proses menghafal Al Qur'an dapat dianalisa melalui model Memletics Learning Styles Inventory, yakni gaya belajar (baca: menghafal) yang dibagi menjadi tujuh bagian, antara lain: 1). Gaya Menghafal Visual, 2). Gaya Menghafal Aural, 3). Gaya Menghafal Verbal, 4). Gaya Menghafal Kinestetik, 5). Gaya Menghafal Logikal, 6). Gaya Menghafal Sosial, dan 7). Gaya Menghafal Solitori.
\end{abstract}

Kata Kunci: Pendidikan Tahfiz, Learning Styles, Sekolah Dasar 


\section{PENDAHULUAN}

Mengapa menghafal Al Qur'an ditekankan dalam konteks kehidupan seharihari, khususnya di dalam lingkungan pendidikan ? Hal tersebut dikarenakan Al Qur'an memiliki keutamaan tersendiri bagi seseorang yang menghafal dan menjaganya. Dari beberapa literatur kajian ilmu Al Qur'an disebutkan bahwa, penghafal Al Qur'an akan memiliki keistimewaan baik di dalam kehidupan di dunia, maupun kehidupan setelahnya, yakni kehidupan di akhirat kelak.

Salah satu keistimewaan penghafal Al Qur'an adalah para penghafal Al Qur'an akan mendapatkan surga di tingkatan tertinggi. Dalam hadis, Rasulullah SAW bersabda, “Jumlah tingkatan surga itu sama dengan jumlah ayat Al Qur'an, maka tingkatan surga yang dimasuki para ahli Al Qur'an merupakan tingkatan paling atas, di mana tidak ada lagi tingkatan setelahnya." (HR. Al Baihaqi). Keistimewaan tersebut semakin terasa bagi umat Islam dan akan terus diperjuangkannya apalagi di tengah-tengah era disrupsi yang serba tak menentu ini. Tentu peran pendidikan menjadi penting dalam mengkonstruksi pemahaman peserta didik tentang keistimewaan tersebut. Karena dengan menghafal Al Qur'an, peserta didik mendapat meningkatkan pendidikan karakter dalam diri peserta didik itu sendiri, baik dalam konteks sosial kehidupan kesehariannya, tetapi juga dalam spiritual individu mereka. Ini yang menjadi titik penting mengapa penggalakan program pendidikan tahfiz di sekolah-sekolah saat ini terus dilakukan.

Learning style atau yang biasa disebut dengan gaya belajar merupakan pengembangan dari belajar itu sendiri. Dalam buku "Teori-Teori Belajar", dijelaskan bahwa belajar merupakan proses di mana organisme akan merubah perilaku seseorang dikarenakan adanya pengalaman dalam dirinya. ${ }^{2}$ Yakni, belajar merupakan aktivitas yang disengaja, bukan dari hasil konstruksi belajar dengan sendirinya. Dengan kesengajaan tersebut, ada aktivitas yang direncanakan

\footnotetext{
${ }^{1}$ Menurut Al Hakim, hadis ini termasuk hadis Shahih, tetapi matan di dalam hadis ini tidak tertulis kecuali dari jalur ini, sehingga hadis ini termasuk hadis Syawadz. Sedangkan menurut Al Suyuthi, hadis ini termasuk hadis Hasan. Lihat Al Suyuthi, Al Jami' Al Shaghir, Juz 2, hlm. 151.

${ }^{2}$ Ratna Wilis Dahar, Teori-teori Belajar, (Jakarta: Erlangga, 1999), hlm. 11.
} 
secara baik, sehingga hasil yang didapatkan adalah perilaku yang baik pula. ${ }^{3}$ Begitu juga sebaliknya, jika perencanaan kurang baik, maka akan menghasilkan perilaku kurang baik juga. Tidak bisa dipungkiri, setiap individu memiliki perbedaan satu sama lain, tak terkecuali dalam konteks belajarnya. Ada yang cepat dalam perubahan yang dihasilkan dari aktivitas belajarnya, ada pula yang membutuhkan waktu yang cukup lama dalam proses perubahan perilaku dari aktivitas belajarnya tersebut.

Gaya belajar anak merupakan sesuatu yang memiliki urgensi yang sangat penting dalam mengoptimalkan potensi pendidikan anak, sehingga seseorang yang menjadi pengajar atau pembelajar harus memperhatikannya dengan baik. Gaya belajar sendiri merupakan cara yang sifatnya individu untuk memperoleh dan menyerap informasi dari lingkungan belajar. Gaya belajar adalah kunci untuk mengembangkan kinerja baik dalam pekerjaan di sekolah, di kantor dan dalam situasi pribadi. Ketika seseorang memahami dan menyadari bagaimana dirinya dan orang lain menyerap serta mengolah informasi, maka ia harus dapat menjadikan belajar dan berkomunikasi yang lebih mudah dengan menggunakan gaya belajar yang mereka temukan. ${ }^{4}$

Berdasarkan dari beberapa hasil pengamatan penulis dan diperkuat adanya penelitian dari Kementerian Agama, ${ }^{5}$ terdapat dampak positif dari kebijakan Madrasah Ibtidaiyah yang telah menyelenggarakan program tahfiz di dalam civitas akademikanya. Dengan adanya program tahfiz ini, para peserta didik tidak hanya mampu membaca Al Qur'an dengan benar sesuai kaidah ilmu Al Qur'an, tetapi adanya program tahfiz ini mampu melahirkan prestasi penghafal Al Qur'an yang disertai prestasi lainnya. Maka tidak jarang para peneliti dan mengkaji ilmu Al Qur'an mengkaitkan antara menghafal Al Qur'an dengan prestasi keilmuan lain. Hal tersebut tentu memiliki kebenaran, karena dengan menghafal Al Qur'an, peserta didik dituntut untuk konsentrasi lebih, disiplin, menghargai waktu, dan

\footnotetext{
${ }^{3}$ M. Joko Susilo, Gaya Belajar Menjadi Makin Pintar (Yogyakarta: Pinus Book Publisher, 2006), hlm. 15.

${ }^{4}$ Bobbi DePorter and Mike Hernacki, Quantum Learning (Bandung: Kaifa, 2001), hlm. 110

${ }^{5}$ Lihat lebih lanjut Nadzif, Kata Pengantar dalam Modul Pembelajaran Tahfizh di Madrasah Ibtidaiyah (Yogyakarta: Bidang Pendidikan Madrasah, 2018), hlm. vii
} 
terus menjaga dari hal-hal yang negatif yang bisa merusak fungsi otak dalam menerima ilmu.

Maka dari itu, menjadi penting diungkapkan bagaimana merekonsepsi pendidikan tahfiz Al Qur'an usia sekolah dasar (khususnya di Madrasah Ibtidaiyah) melalui model learning styles (gaya belajar) dari diri peserta didik itu sendiri. Ini bertujuan bahwa jika pendidikan tahfiz Al Qur'an diimplementasikan sesuai dengan gaya belajar peserta didik, maka dalam segi kognitif, afektif, dan psikomotorik mereka dapat tercapai lebih baik dan potensi pengembangan pendidikan anak lebih maksimal.

\section{KAJIAN LITERATUR}

Dalam konteks pembelajaran yang optimal anak, perlu dipahami secara lebih spesifik bagaimana perbedaan gaya belajar dari masing-masing anak. Menurut Gunawan, terdapat tujuh pendekatan yang sering dikenal dengan kerangka referensi yang berbeda, antara lain:

1) Pendekatan berdasarkan pada pemprosesan informasi. Yakni menentukan cara yang berbeda dalam memandang dan memproses informasi yang baru; ${ }^{6}$

2) Pendekatan berdasarkan pada kepribadian. Yakni menentukan karakter yang berbeda; ${ }^{7}$

3) Pendekatan pada modalitas sensori. Yakni menentukan tingkat ketergantungan terhadap indera tertentu; ${ }^{8}$

4) Pendekatan berdasarkan lingkungan. Yakni menentukan respons yang berbeda terhadap kondisi fisik, psikologis, sosial, dan instruksional ${ }^{9}$

${ }^{6}$ Pendekatan ini dibagi menjadi empat kuadran, sebagaimana yang dikemukakan dalam David A. Kolb, Experiential Learning: Experience as The Source of Learning and Developtment, (New York: Prentice-Hall, 1984).

${ }^{7}$ Pendekatan ini dikembangkan dengan model Myer-Briggs, dan juga model Holland. Lihat Zaman S. dan Abdillah S.A., MBTI (Myers-Briggs Type Indicator): Cara Menggali Potensi Diri untuk Meraih Kesempatan Kerja, (Jakarta: Visimedia, 2009).

${ }^{8}$ Dalam pendekatan ini, pembelajaran harus menyesuaikan dengan modalitas-modalitas agar dapat tercapai hasil yang maksimal. Lihat Michael Grinder, Richting of Educational Conviyer Belt, (Portland Ore: Methamorphous Press, 1991).

${ }^{9}$ Pendekatan ini dilakukan dan dikembangkan oleh Andreas Herman Witkin, Oltman, Raskin, dan Krap sejak tahun 1940 sampai dengan tahun 1970 dengan melibatkan 1000 mahasiswa. Sehingga dengan adanya pengembangan tersebut, mereka menemukan gaya belajar "Field 
5) Pendekatan berdasarkan pada interaksi sosial. Yakni menentukan cara yang berbeda dalam berhubungan dengan orang lain; ${ }^{10}$

6) Pendekatan berdasarkan pada kecerdasan. Yakni menentukan bakat yang berbeda; ${ }^{11}$

7) Pendekatan berdasarkan pada wilayah otak. Yakni, menentukan dominasi relatif dari berbagai bagian otak, misalnya otak kiri dan kanan. ${ }^{12}$

Beberapa pandangan tersebut menunjukkan bahwa gaya belajar seseorang memiliki perbedaan yang cukup signifikan. Hal ini dikarenakan dari beberapa pendekatan memiliki sudut pandang yang berbeda. Dari pendekatan di atas, juga dapat dipahami jika gaya belajar adalah bagaimana cara seseorang (anak) bereaksi dan menggunakan stimulus tertentu di dalam dirinya sendiri untuk memproses informasi (ilmu pengetahuan) yang didapatkan. Gaya belajar seseorang merupakan kombinasi bagaimana ia menyerap, mengatur, dan mengolah informasi. ${ }^{13}$ Dalam artian, secara umum gaya belajar merupakan cara efektif yang disukai oleh seseorang (peserta didik) dalam menyerap, mengolah, mengatur, memahami, mengingat informasi yang diperoleh serta memecahkan masalah yang

Dependence" dan "Field Independence". Maka dari itu, pendekatan ini dikenal dengan Model Witkin, Oltman, Raskin, dan Karp. Lihat Atkinson H. Witkin, Oltman, P.K.., Raskin, E., \& Karp, S.A., The Effect of Training and Structural Aids of Performance in Threes Test of Space Orientation, (Washington D.C.: Civil Aeronautics Adminisitration, Division of Research, 1971).

${ }_{10}$ Pendekatan ini juga disebut dengan gaya belajar model sosial yang dikembangkan oleh Sheryl Kruska K. dan Anthony Grasha. Di sini dapat diidentifikasi tiga bentuk tipe pendekatan individual terhadap situasi belajar, yaitu Avoidant, Competitive, dan Independent. Lihat Grasha, A.F., Learning Styles: The Journey from Greenwich Observatory to the College Classroom, Improving College and University Teaching, Vol. 32, 1983.

${ }^{11}$ Pendekatan ini banyak dikembangkan di Indonesia. Dalam pendekatan ini dijelaskan bahwa setiap orang memiliki macam-macam kecerdasan yang berbeda. Kemampuan terhadap kecerdasan yang berbeda itulah yang menjadi dasar dalam mengklasifikasikan gaya belajar seseorang. Lihat Howard Gardner, Intellegence Reframed, (New York: Basic Books, 1999). Juga lihat Thomas Amstrong, Kecerdasan Multipel di dalam Kelas, Terj. (Jakarta: Indeks, 2013).

12 Pendekatan ini dikembangkan oleh Bogm dan Edward. Lihat Adi. W. Gunawan, Genius Learning Style Strategy: Petunjuk Praktis untuk Menerapkan Accelerated Learning, (Jakarta: PT Gramedia Pustaka Utama, 2012).

${ }^{13}$ Lihat B. DePorter, and M. Hernacki, Quantum Learning: Membiasakan Belajar Nyaman dan Menyenangkan, (Bandung: Kaifa, 2010). 
ia hadapi dalam konteks aktivitas belajar dengan berinteraksi dalam merespon lingkungan di mana ia belajar. ${ }^{14}$

Gaya belajar seseorang pada dasarnya sudah banyak dijelaskan melalui berbagai teori oleh para ahli. Pada umumnya, gaya belajar seseorang dibagi menjadi tiga kategori besar, ${ }^{15}$ antara lain:

\section{1) Gaya Visual}

Maksud dari gaya visual ini adalah seseorang lebih menyukai belajar dalam memproses ilmu pengetahuan melalui penglihatan. Peserta didik dengan gaya belajar seperti ini menitikberatkan pada penglihatan untuk melihat bukti terlebih dahulu sebelum mereka mempercayai dan memahami informasi yang didapatnya.

\section{2) Gaya Auditorial}

Maksud dari gaya auditorial ini adalah seseorang lebih menikmati proses menyerap ilmu pengetahuan melalui pendengaran. Gaya belajar dari peserta didik seperti ini adalah secara serius menempatkan pendengaran dari dirinya sebagai alat utama menyerap informasi dan ilmu pengetahuan yang didapat. Di sini peserta didik harus mendengar, kemudian dapat mengingat serta memahami informasi dan ilmu pengetahuan tersebut.

\section{3) Gaya Kinestetik}

Maksud dari gaya kinestetik ini adalah seseorang lebih menyukai belajar, memahami dan menyerap sesuatu melalui gerakan atau praktik. Gaya belajar dari peserta didik seperti ini adalah mengharuskan ia bersentuhan langsung dengan sesuatu (melalui pengalaman langsung), sehingga informasi dan ilmu pengetahuan yang didapatkan dapat terserap dengan baik.

\footnotetext{
${ }^{14}$ Ibnu R. Khoeron, Nana Sumarna, Tatang Permana, Pengaruh Gaya Belajar Terhadap Prestasi Belajar Peserta Didik pada Mata Pelajaran Produktif, Journal of Mechanical Engineering Education, Vol. 1 No. 2, Desember 2014, hlm. 292.

${ }^{15}$ Lihat Bobbi DePorter, Mark Reardon \& Sarah Singer-Nourie, Quantum Teaching ........ hlm. 123
} 
Tentu bagi penulis, ketiga kategori gaya belajar di atas belum mampu memberikan gambaran spesifik dari gaya belajar seseorang (peserta didik), khususnya gaya belajar dalam menghafal Al Qur'an. Maka di sini penulis, mencoba merujuk pada gaya belajar peserta didik dalam konteks kecerdasan majemuk (multiple intelligence) yang dikembangkan oleh Howard Gardner. Menurutnya, dalam mengidentifikasi kecerdasan majemuk (multiple intelligence), terdapat sembilan aspek kecerdasan dalam diri peserta didik yang dapat dilihat dan dipahami secara lebih komprehensif, di antaranya: 1). Verbal, 2). Logis, 3). Visual, 4). Musikal, 5). Kinestetik, 6). Antar personal (memahami orang lain), 7). Intra personal (memahami diri sendiri), 8). Naturalis, dan 9). Eksistensial. ${ }^{16}$

Pendekatan kecerdasan majemuk (multiple intelligence) oleh Gardner di atas dieksplorasi kembali secara detail melalui gaya belajar yang disebut Memletics Learning Styles Inventori. Gaya belajar ini tepat untuk melihat gaya belajar peserta didik (khususnya dalam kegiatan tahfiz Al Qur'an pada diri seseorang), karena gaya belajar ini mencoba meringkas dan mewakili apa yang telah dirumuskan oleh Gardner dalam kecerdasan majemuknya tersebut. Maka dari itu, gaya belajar Memletics Learning Styles Inventori dibagi menjadi tujuh bagian. ${ }^{17}$ Secara lebih detail, akan dijelaskan dan dianalisa dengan baik di dalam ruang diskusi dan pembahasan di bawah ini.

\section{PEMBAHASAN}

\section{A. Karakteristik Proses Menghafal Al Qur'an}

Secara spesifik, sangat susah menemukan gaya belajar yang terfokus pada tahfiz Al Qur'an. Tetapi dari berbagai penelitian, disebutkan bahwa peserta didik yang menghafal Al Qur'an dapat lebih mudah ketika ia menggunakan berbagai variasi dan gaya belajar yang dimilikinya. Learning styles (gaya belajar) dalam tahfiz Al Qur'an, penulis cenderung berpijak pada teori yang dipakai oleh Lukman Hakim dan Ali Khosim dengan bukunya, "Metode Ilham: Menghafal Al Qur'an Serasa Bermain Game”. Dalam bukunya ini, ada beberapa karakteristik

\footnotetext{
${ }^{16}$ S. E. Smaldino, Lowther, D. L., \& Russel, J. D., Instructional Technology ...... hlm. 114

${ }^{17}$ Lihat www.memletic.com diakses pada Senin, 18 November 2018 pukul 22.15 WIB.
} 
yang menarik untuk dipahami bagaimana gaya belajar dipakai dalam proses pembelajaran tahfiz Al Qur'an. ${ }^{18}$

1) Menghafal Al Qur'an bisa dilakukan kapanpun

Menghafal Al Qur'an tidak harus menggunakan waktu tertentu. Tentu hal ini memudahkan peserta didik untuk menggunakan target tertentu dalam menghafal, apalagi memiliki target menghafal dalam waktu yang singkat.

2) Menghafal Al Qur'an itu mudah dan menyenangkan

Di dalam bukunya, terdapat beberapa variasi dalam menghafal Al Qur'an, sehingga memudahkan peserta didik dalam menemukan metode yang tepat sesuai dengan gaya belajarnya. Karena dengan menggunakan metode yang tepat sesuai dengan gaya belajar yang dimiliki, maka menghafal Al Qur'an akan lebih efektif, menyenangkan, dan menuai hasil maksimal.

3) Menghafal Al Qur'an harus rileks

Jika menghafal Al Qur'an dengan kondisi yang tegang dan konsentrasi yang terlalu berlebihan sehingga membebani pikiran, maka hasil yang didapatkan pasti kurang maksimal. Maka perlu dibuat rileks. Hal ini tentu sesuai dengan metode yang dipakai, karena di dalam metode Ilham tersebut menghafal Al Qur'an dengan memadukan gaya belajar peserta didik dan melibatkan anggota badan, sehingga terkesan lebih rileks dan santai.

4) Menghafal Al Qur'an dilakukan secara bersama

Hal ini dilakukan karena dengan menghafal secara bersama-sama atau dengan berpasang-pasangan akan memberikan tanggung jawab satu sama lain dalam rangka saling memperhatikan, mengevaluasi, dan memotivasi hafalan. Dengan bersama-sama pula, setidaknya ada kedekatan secara emosional antar teman dan masing-masing akan lebih semangat dalam menjalankan proses menghafalnya.

\footnotetext{
${ }^{18}$ Lukman Hakim dan Ali Khosim, Metode Ilham: Menghafal Al Qur'an Serasa Bermain Game, (Bandung: Humaniora, 2016), hlm. 108-114.
} 
5) Menghafal Al Qur'an harus bersemangat

Di dalam metode ini, menghafal Al Qur'an dilakukan secara bersamasama sebagaimana yang dijelaskan di atas. Ditambah ayat yang dihafalkannya harus diimajinasikan dalam berbagai gerakan badan peserta didik.

6) Hafalan variatif dan bisa dibaca secara terbalik

Dalam artian, metode Ilham yang dipakai ini memiliki karakteristik tersendiri. Hal ini merupakan solusi yang dipakai bagi peserta didik yang menghafal Al Qur'an karena adanya kesulitan mendeteksi letak ayat (surat dan ayat berapa). Maka dengan adanya hal tersebut, dimungkinkan untuk membaca Al Qur'an secara terbalik.

7) Hafal Al Qur'an dan juga harus mahir dalam menulis

Di dalam buku tersebut, selama menghafal Al Qur'an, peserta didik tidak hanya menghafal ayat demi ayat di dalam Al Qur'an, tetapi juga mereka diajarkan mengingat bentuk tulisan ayat yang dihafalkannya tersebut.

Karakteristik gaya belajar yang dipakai dalam proses pembelajaran tahfiz Al Qur'an di atas diperkuatnya bagaimana Rasulullah dan para sahabatnya dalam menghafal dan menjaga Al Qur'an, sebagaimana dijelaskan di bawah:

1) Rasulullah SAW dalam sholat (khususnya dalam qiyamullail) senantiasa mengulangi hafalannya;

2) Konsep Mudarasah Al Qur'an (mengulangi ilmu satu sama lainnya) dilakukan antara Malaikat Jibril dan Rasulullah;

3) Pengajaran Al Qur'an di Makkah dan Madinah dilakukan oleh Rasulullah SAW kepada para sahabatnya;

4) Konsep Tilawah dan pengajaran yang dilakukan oleh para sahabat (khususnya dalam mengkhatamkan Al Qur'an dan mengajarkannya kepada orang lain). ${ }^{19}$

\footnotetext{
${ }^{19}$ Farid Wajdi, Tahfiz Al Qur'an dalam Kajian Ulumul Qur'an (Studi Atas Berbagai Metode Tahfiz), Tesis, (Jakarta: UIN Jakarta, 2008), hlm. 65-73
} 


\section{B. Model Learning Styles dalam Tahfiz Al Qur'an}

Untuk memudahkan dalam menghafal dan menghasilkan hafalan yang kuat, setidaknya ada tujuh kecerdasan yang harus diterapkan dengan berlandaskan pada gaya belajar peserta didik itu sendiri. Tujuh kecerdasan tersebut antara lain:

1) Kecerdasan Linguistik

Kecerdasan ini diperlukan karena memiliki fungsi untuk melafalkan ayatayat Al Qur'an secara benar. Kecerdasam ini dapat dilakukan dan diasah dengan cara menyimak, memperhatikan, dan menirukan guru pembimbing dalam melafalkan suatu ayat dengan memperhatikan makharijul huruf, panjang pendek huruf dan ilmu tajwid lainnya.

2) Kecerdasan Matematik

Kecerdasan ini memiliki fungsi yang baik, karena untuk menghafal urutan nomor halaman, nomor surat, jumlah ayat dalam suatu surat, jumlah suatu halaman, dan seterusnya. Maka guru pembimbing harus terus menanyakan poin-poin tersebut dalam rangka mengasah kecerdasan matematik ini. Hal ini dilakukan tidak hanya peserta didik hafal redaksi dalam ayat, tetapi juga hafal urutan nomor ayat, nomor surat, dan nomor halaman yang mereka hafalkan.

3) Kecerdasan Visual

Kecerdasan ini sangat penting diperhatikan dalam menghafal Al Qur'an, karena memiliki fungsi untuk melihat ayat demi ayat secara akurat. Dalam menghafal Al Qur'an, peserta didik yang memiliki gaya belajar visual yang baik, ia akan dapat menuliskan ayat-ayat yang telah dihafalkannya, sekaligus hafal letak dalam suatu hafalannya.

4) Kecerdasan Musikal

Kecerdasan ini digunakan dalam menghafal Al Qur'an karena memiliki fungsi untuk menikmati ritme, melodi, dan suara-suara yang didengarkan. Dalam praktik menghafal Al Qur'an, peserta didik dibiasakan untuk melantunkan ayat-ayat Al Qur'an secara tartil dan berirama dengan baik. Bahkan hal tersebut dilakukan dengan cara mengetukkan jari tangan untuk menyeragamkan irama lagu tartilnya tersebut. 


\section{5) Kecerdasan Kinestetik}

Kecerdasan ini juga perlu dilakukan bagi peserta didik yang menghafal Al Qur'an. Kecerdasan ini berfungsi untuk mengingat nomor ayat dan biasanya anggota tubuh digunakan adalah jari-jari tangan. Dalam realitas di lapangan, banyak peserta didik lebih nyaman menghafal Al Qur'an ketika ia menggerakkan kaki dan anggota tubuh lainnya selama proses menghafal.

6) Kecerdasan Interpersonal

Kecerdasan ini juga perlu dibangun bagi mereka yang menghafal Al Qur'an. Hal ini berfungsi untuk saling memberikan motivasi dan dorongan agar antar peserta didik saling menguatkan dan memberikan semangat dalam menghafal Al Qur'an. Di samping untuk memberikan motivasi, kecerdasan ini juga berfungsi untuk saling mengevaluasi dan mencocokkan hafalan antar teman satu dengan yang lainnya. Kecerdasan ini akan membuat peserta didik menjadi peka dan bertanggung jawab atas kebenaran hafalan dari pasangan kelompoknya.

7) Kecerdasan Intrapersonal

Dalam kecerdasan intrapersonal ini, peserta didik dituntut untuk mengembangkan sikap mandiri dari dirinya sendiri, disiplin dalam menghafal, menghargai setiap waktu yang diberikan, dan tangguh dalam menghadapi segala tantangan dalam proses menghafal Al Qur'an. Jika kecerdasan intrapersonal dapat diaplikasikan dalam diri peserta didik, mereka akan memiliki kesadaran yang timbul dalam dirinya sendiri dalam rangka menyelesaikan hafalannya dalam jangka waktu yang tepat sesuai dengan apa yang diharapkan.

Tidak hanya beberapa model di atas dalam mengimplementasikan gaya belajar (learning styles), tetapi terdapat pula gaya belajar yang disebut Memletics Learning Styles Inventory. ${ }^{20}$ Gaya belajar ini juga tepat untuk melihat gaya belajar

\footnotetext{
${ }^{20}$ Lihat www.memletic.com diakses pada Senin, 24 Februari 2020 pukul 10.15 WIB. Dalam model Memletics Learning Styles Inventory ini, dijelaskan bahwa gaya belajar peserta didik dapat dibedakan menjadi tujuh bagian, yakni 1). Visual, 2). Aural, 3). Verbal, 4). Kinestetik, 5). Logikal, 6). Sosial, dan 7). Solitori
} 
peserta didik dalam kegiatan tahfiz Al Qur'an di Madrasah Ibtidaiyah. Gaya belajar (baca: menghafal) Memletics Learning Styles Inventory ini dibagi menjadi tujuh bagian, di antaranya:

\section{1) Gaya Menghafal Visual}

Peserta didik penghafal Al Qur'an yang memiliki gaya belajar ini lebih menyukai proses hafalannya dengan menggunakan penglihatan ayat demi ayat di dalam Mushaf Al Qur'an secara langsung, apalagi jika mushaf memiliki beberapa warna tertentu dan di-setting bagi penghafal Al Qur'an. Peserta didik dengan tipe ini identik dengan suka mencoret-coret sesuatu ketika sedang belajar dan menghafal. Terkadang individu ini menghafal Al Qur'an sambil menulis ayat yang dihafalkannya. Dari berbagai penelitian menyebutkan peserta didik yang memiliki gaya belajar visual ini dapat meningkatkan prestasi belajarnya. ${ }^{21}$

Untuk memberikan solusi jika terdapat peserta didik penghafal Al Qur'an di Madrasah Ibtidaiyah, terdapat teknik pembelajaran yang tepat yang bisa dilakukan oleh peserta didik tersebut dengan dibimbing oleh guru pembimbingnya. Teknik tersebut antara lain: a). Gunakan mushaf khusus untuk penghafal Al Qur'an, seperti Al Qur'an Tikrar yang dilengkapi dengan kolom bacaan, ayat penanda awal dan akhir blok, dan blok warna untuk hiasan, ${ }^{22}$ dan b). Teknik visualisasi cerita membantu peserta didik penghafal Al Qur'an untuk memudahkan dalam menghafal ayat-ayat dengan membandingkan sesuatu yang abstrak, seperti pemutaran video tartil Al Qur'an dan seterusnya.

\section{2) Gaya Menghafal Aural}

Peserta didik penghafal Al Qur'an dengan gaya belajar aural lebih menyukai belajar ketika adanya suara yang berirama (musik). Kaitannya dengan musik/nada, seseorang dengan gaya ini terbantu karena memiliki otak yang lebih berperan

\footnotetext{
${ }^{21}$ D. Priyatno, Mandiri Belajar SPSS, (Yogyakarta:MediaKom, 2008), hlm.77

${ }^{22}$ Mushaf Al Qur'an yang dimaksud seperti Mushaf Syaamul Qur'an terbitan dari PPPA Daarul Qur'an bimbingan ustadz Yusuf Mansur. Mushaf tersebut sengaja dicetak bagi masyarakat yang ingin menghafal Al Qur'an dengan mudah. Karena di situ dilengkapi beberapa metode menghafal, pewarnaan setiap awal dan akhir ayat, dan seterusnya.
} 
pada proses verbal, yakni proses mendengar sebagai pengirim berita. ${ }^{23}$ Biasanya peserta didik seperti ini mudah menghafal ayat Al Qur'an dengan beberapa variasi nada tartil Al Qur'an yang selama ini sudah berkembang. Ia akan lebih mudah mengenali suara dari nada tartil imam (syekh) satu dengan yang lain yang berbeda, seperti nada tartil Al Qur'an dari Syekh As Sudais, Syekh Misyari Rasyid, dan seterusnya.

Peserta didik penghafal Al Qur'an dengan tipe ini cenderung menggunakan beberapa cara, antara lain: a). Menggunakan sarana suara dari guru pembimbing di kelas, dan b). Menggunakan rekaman nada suara tartil dari media (MP3, MP4, HP, dan seterusnya dalam pembelajaran menghafal.

\section{3) Gaya Menghafal Verbal}

Peserta didik penghafal Al Qur'an dengan gaya belajar verbal ini sering menggunakan kata-kata dalam proses belajarnya. Peserta didik dengan gaya belajar verbal ini lebih suka bermain dengan kata-kata, baik ekspresi kata melalui tulisan maupun lisan. Maka di sini, peserta didik dengan gaya verbal ini lebih mengetahui banyak arti kata dari beberapa ayat dihafalkannya. Secara teratur, ia berusaha untuk menemukan arti dari kata-kata baru setiap ia mendapatkan ilmu pengetahuan dari apa yang dihafalkannya di dalam Al Qur'an dan dari ilmu-ilmu Al Qur'an lainnya.

\section{4) Gaya Menghafal Kinestetik}

Peserta didik penghafal Al Qur'an dengan gaya belajar kinestetik akan lebih banyak menggunakan gerakan serta indera peraba dalam proses menghafal Al Qur'an. Peserta didik ini lebih menyukai hal-hal yang terkait gerakan dan kegiatan yang berhubungan dengan aktifitas fisik. Sebaliknya, peserta didik dengan tipe ini tidak menyukai untuk duduk diam terlalu lama. Semakin ia bergerak, semakin ia lebih mudah dalam menghafal. Selama proses menghafal,

\footnotetext{
${ }^{23}$ Fikri, Mohammad Tsaqibul. "Penguatan Nilai Agama pada Anak Berkebutuhan Khusus (Tunanetra) melalui Seni Musik." Al Ulya 2.II (2017): 151-164.
} 
biasanya peserta didik dengan gaya belajar ini selalu menggerakkan tangan, kaki, atau anggota tubuh yang lainnya.

\section{5) Gaya Menghafal Logikal}

Peserta didik dengan gaya belajar ini sering menggunakan sesuatu secara logis dan lebih menyukai aktifitas berpikir setiap ia menghafal ayat Al Qur'an, apalagi ketika ia memahami arti dari ayat yang dihafalkannya tersebut. Peserta didik dengan tipe ini dengan mudah mengenali pola serta hubungan antar konten dan senang menetapkan target dalam menghafal. Tidak hanya itu, peserta didik penghafal Al Qur'an dengan tipe ini lebih menyukai membuat perencanaan dalam menghafal, serta mengklasifikasikannya sebelum mengerjakannya dalam kurun waktu tertentu.

Peserta didik dengan gaya belajar ini cenderung menggunakan beberapa cara, antara lain: a). Menghafal ayat Al Qur'an menjadi hal yang mudah, tetapi memahami arti dari ayat tersebut akan lebih memudahkan untuk mengingat serta mempelajari ayat demi ayat selanjutnya, dan b). Pada saat menghafal, tipe ini akan lebih mudah menggunakan daftar atau penanda dengan menemukan poin-poin penting pada setiap ayat-ayat yang baru ditemukannya.

\section{6) Gaya Menghafal Sosial}

Peserta didik penghafal Al Qur'an dengan gaya belajar sosial ini lebih mudah berkomunikasi dengan orang lain secara verbal dan non-verbal. Tipe peserta didik ini lebih suka menghafal Al Qur'an secara berkelompok atau berpasangan dengan teman. Hal tersebut tidak hanya membuatnya lebih nyaman dalam menghafal, tetapi juga dapat memberikan makna simbiosis mutualisme antara dia dan temannya, dalam artian satu sama lain saling mengkoreksi hafalan dan bacaan ketika terdapat kesalahan.

Peserta didik dengan tipe ini cenderung menggunakan beberapa cara, antara lain: a). Model pembelajaran berpasang-pasangan (berkelompok) merupakan model pembelajaran yang paling sesuai, b). Dengan mendengarkan orang lain menghafal dan memperbaiki kesalahan hafalan, peserta didik ini justru akan 
mendapat ide untuk mengatasi masalah hafalannya sendiri, dan c). Mudah membagikan hafalan yang ia dapatkan kepada orang lain. Hal itu akan memudahkan belajar menghafal Al Qur'an dari dirinya.

\section{7) Gaya Menghafal Solitori}

Peserta didik penghafal Al Qur'an dengan gaya belajar solitori ini adalah individu yang lebih pribadi dan mandiri. Tipe ini akan lebih banyak menghafal Al Qur'an dengan menyendiri dan ia memikirkan rintangan dan tantangan yang dihadapi selama proses menghafalnya. Saat belajar menghafal dengan tekanan, peserta didik dengan tipe ini lebih menyukai untuk menghindar dan mencari tempat sepi. Maka tidak mengherankan jika peserta didik dengan tipe ini lebih suka melakukan berbagai aktifitasnya secara individualistik dan menjauh dari halhal sosialistik.

Beberapa model gaya belajar untuk peserta didik yang menghafal Al Qur'an di atas menjadi penting untuk diimplementasikan di beberapa sekolah dasar di Indonesia, khususnya di lingkungan Madrasah Ibtidaiyah. Hal ini karena pertumbuhan dan perkembangan program tahfiz Al Qur'an di Madrasah Ibtidaiyah semakin tahun semakin memberikan manfaat bagi masyarakat. Adanya aktualisasi program tahfiz dengan mengoptimalkan gaya belajar peserta didik tentu bisa membangun motivasi warga madrasah yang gemar belajar dan membaca Al Qur'an, meningkatkan religiusitas civitas akademika, dan mampu membumikan nilai-nilai Al Qur'an di dalamnya. Ini bertujuan agar peserta didik memiliki karakter yang kuat dalam dirinya, dan mampu meningkatkan semangat belajar yang tinggi, sehingga akan berdampak pada prestasi dirinya sendiri, prestasi civitas akademika (sekolah) dan prestasi dunia pendidikan Islam pada umumnya. $^{24}$

Tidak bisa dipungkiri kembali bahwa perkembangan tahfiz di Madrasah Ibtidaiyah semakin hari trennya semakin meningkat. Hal ini diperkuat dari hasil penelitian dan telah dilansir oleh media republika.co.id yang mengatakan bahwa

\footnotetext{
${ }^{24}$ Ahmad Farid dan Ismail, Modul Pembelajaran Tahfiz Madrasah Ibtidaiyah, (Yogyakarta: Bidang Pendidikan Madrasah Kanwil Kemenag DIY, 2018), hlm. viii
} 
tren menghafal Al Qur'an di Indonesia semakin berkembang setiap tahun. ${ }^{25}$ Maka dari itu, rekonsepsi pendidikan tahfiz Al Qur'an yang dibarengi dengan model gaya belajar peserta didik perlu dipertimbangkan dan diimplementasikan secara komprehensif agar ke depan menjadi fenomena pendidikan Islam yang menggembirakan dan mampu diterima oleh masyarakat secara global.

\section{KESIMPULAN}

Perkembangan program tahfiz Al Qur'an di Sekolah Dasar, khususnya Sekolah Dasar Islam (Madrasah Ibtidaiyah) dalam kurun waktu sepuluh tahun terakhir ini semakin hari semakin berkembang pesat. Hal ini memerlukan pemikiran tersendiri untuk mengoptimalkan program tersebut sehingga mampu menjadi pendidikan tahfiz yang unggul, baik unggul dalam kualitas hafalannya, maupun unggul dalam kualitas pendidikan umum lainnya di ruang-ruang pendidikan formal. Memahami hal tersebut, perlu adanya rekonsepsi pendidikan tahfiz Al Qur'an melalui penggunaan model learning styles (gaya belajar) dalam diri peserta didik itu sendiri. Adanya rekonsepsi ini diharapkan mampu membangun motivasi warga sekolah (khususnya peserta didik) untuk terus mengaji dan mengkaji Al Qur'an dan pada akhirnya akan memasyarakatkan Al Qur'an dan meng-Al Qur'an-kan masyarakat. Tidak hanya itu, optimalisasi pendidikan tahfiz ini juga akan berdampak pada karakter peserta didik yang kuat secara emosional, sosial, dan spiritual, sehingga tercipta apa yang selama ini diharapkan oleh Pendidikan Nasional.

25 Lihat https://www.republika.co.id/berita/dunia-islam/khazanah/13/09/18/mtaab3-trenmenghafal-alquran-makin-berkembang diakses pada 12 Februari 2020 pukul 09.00 WIB. 


\section{DAFTAR PUSTAKA}

Amstrong, Thomas, Kecerdasan Multipel di dalam Kelas, Terj. (Jakarta: Indeks, 2013).

Dahar, Ratna Wilis, Teori-teori Belajar (Jakarta: Erlangga, 1999).

DePorter, Bobbi and Mike Hernacki, Quantum Learning (Bandung: Kaifa, 2001).

Farid, Ahmad dan Ismail, Modul Pembelajaran Tahfiz Madrasah Ibtidaiyah, (Yogyakarta: Bidang Pendidikan Madrasah Kanwil Kemenag DIY, 2018).

Fathoni, Ahmad, Sejarah \& Perkembangan Pengajaran Tahfiz Al Qur'an di Indonesia, diakses dari http://www.baq.or.id/ pada 2 Januari 2020.

Fikri, Mohammad Tsaqibul. "Penguatan Nilai Agama pada Anak Berkebutuhan Khusus (Tunanetra) melalui Seni Musik." Al Ulya 2.II (2017): 151-164.

Ghufron, M. Nur dan Rini Risnawita, Gaya Belajar: Kajian Teoritik (Yogyakarta: Pustaka Belajar, 2013).

Grasha, A.F., Learning Styles: The Journey from Greenwich Observatory to the College Classroom, Improving College and University Teaching, Vol. 32, 1983.

Grinder, Michael, Richting of Educational Conviyer Belt (Portland Ore: Methamorphous Press, 1991).

Gunawan, Adi W., Genius Learning Strategy: Petunjuk Praktis untuk Menerapkan Accelerated Learning (Jakarta: PT Gramedia Pustaka Utama, 2012).

Hakim, Lukman dan Ali Khosim, Metode Ilham: Menghafal Al Qur'an Serasa Bermain Game (Bandung: Humaniora, 2016).

H., Atkinson, Witkin, Oltman, P.K.., Raskin, E., \& Karp, S.A., The Effect of Training and Structural Aids of Performance in Threes Test of Space Orientation (Washington D.C.: Civil Aeronautics Adminisitration, Division of Research, 1971).

https://www.republika.co.id/berita/dunia-islam/khazanah/13/09/18/mtaab3-trenmenghafal-alquran-makin-berkembang diakses pada 12 Februari 2020.

-------, Mushaf Syaamil Qur'an, (Bandung: PPPA Daarul Qur'an, 2015)

Kolb, David A., Experiential Learning: Experience as The Source of Learning and Developtment (New York: Prentice-Hall, 1984).

Khoeron, Ibnu R., Nana Sumarna, Tatang Permana, Pengaruh Gaya Belajar Terhadap Prestasi Belajar Peserta Didik pada Mata Pelajaran Produktif, Journal of Mechanical Engineering Education, Vol. 1 No. 2, Desember 2014

Nadzif, Modul Pembelajaran Tahfizh di Madrasah Ibtidaiyah. Kata Pengantar (Yogyakarta: Bidang Pendidikan Madrasah, 2018)

Priyatno, D., Mandiri Belajar SPSS, (Yogyakarta:MediaKom, 2008). 
S., Zaman dan Abdillah S.A., MBTI (Myers-Briggs Type Indicator): Cara Menggali Potensi Diri untuk Meraih Kesempatan Kerja (Jakarta: Visimedia, 2009).

Susilo, M. Joko, Gaya Belajar Menjadi Makin Pintar (Yogyakarta: Pinus Book Publisher, 2006).

Suyuthi, Al, Al Jami' Al Shaghir, Juz 2

Wajdi, Farid, Tahfiz Al Qur'an dalam Kajian Ulumul Qur'an (Studi Atas Berbagai Metode Tahfiz), Tesis (Jakarta: UIN Jakarta, 2008). 